\title{
Epistolarne konwencje grzecznościowe w listach do redakcji czasopisma religijnego „Miłujcie się!"
}

Katarzyna Czarnecka 


\title{
Katarzyna Czarnecka
}

\section{Epistolarne konwencje grzecznościowe w listach do redakcji czasopisma religijnego „Miłujcie się!”}

\begin{abstract}
Tednym z obszarów realizacji etykiety językowej, rozımianej jako zbiór przyjętych w danej spoleczności wzorów językowych zachowań grzecznościowych, zwyczajowo przyporząd-

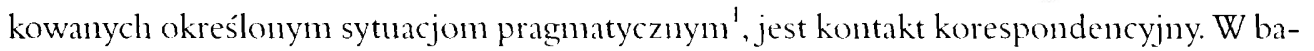
daniach nad tekstem epistolarnym, czyli „wypowied zią pisemną skierowaną do określonego adresata, powiadamiającą go o czymś lub nakłaniającą do jakichś zachowań”, stosunkowo mało miejsca poświęcono dotąd listom do redakcji. Opracowania prasoznawców i lingwistów dotyczą zwykle listów wydrukowanych na łamach prasy, poddanych zatem przynajmuicj elementarnym zabiegom redakcyjnym ${ }^{3}$. Stou'nik pojeć i tekstón kultury uznaje opublikowane listy za gatunek publicystyczny, wypowiedź powstalą spontanicznie, z inicjatywy czytelnika lub też sfingowaną przez pracowników redakcji w celu stworzenia pozorowanego dialogu z odbiorcami tekstów ${ }^{+}$. W niniejszym artykule, dotyczącym listów do redakcji, przedmiotem moich zainteresowań czynię inny materiak: autentyczną, n i e d r uk ow a n ą korespondencję, napływającą do wydawanego w Poznaniu od 1975 roku religijnego periody-
\end{abstract}

\footnotetext{
'M. Marcjanik. Etjkicta jezpkon'a, [w: | I'spoitcz'suly jezyk polkki. red. J. Bartminiski. Wroctaw 1993, s. 270.

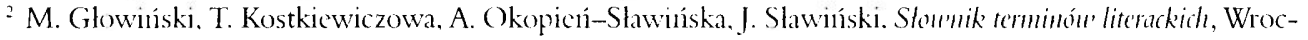
law-Warszawa 1988. s. 256.

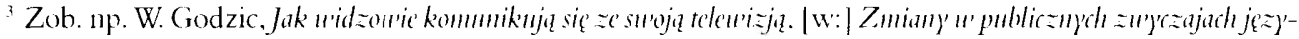
kou'ych, red. J. Bralczyk, K. Musiolck-Klosińska, Warszawa 2001, s. 160)-176: M. Wojtak, Stylist)k'a listón do re-

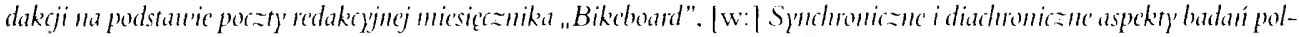
szizy:my, t. 8, red. M. Bialoskórska, L. Mariak. Szczecin 20112. s. 195-214: A. Dąbrowska, Sposoly okrestania

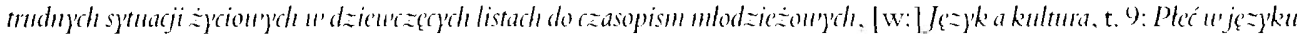
ikulturze, red.J. Anusiewicz. K. Handke, Wrodaw 1994. s. 187-199, M. Szpakowska. Listy'u'spraurach osobistyith na tamaih prasy'. .. Napis", scria IX. Warszawa 20013. s. 229-236.

+ Por. Stou'mik poję́ i tekstón' kultury'. Terytoria stou'a, red. E. Szczęsna. Warszawa 2002, s. 102.
} 
ku ,.Miłujcie się!””. Analizie poddaję korpus 400 listów w wersji oryginalnej. zwykle rękopiśmiennej (rzadziej w postaci wydruku komputerowego). Podstawę badań stanowi wydobyta $z$ archiwum redakcyjnego poczta z lat 1999-2003, nadesłana przez ludzi młodych (w wieku od 15 do 30, wyjątkowo 35 lat)". Ewentualna późniejsza publikacja niektórych tekstów pozostaje poza obszarem rozważań.

Model listu do redakcji wykazuje liczne podobieństwa do struktury listu prywatnego ${ }^{7}$. O specyfice listu do redakcji, będącego podstawową formą kontaktu czytelnika z zespolem przygotowującym czasopismo, niekiedy też z autorani poszczególnych artykułów, decyduje stosunkowo trudna sytuacja komunikacyjna. Jej podstawowy wyznacznik to, przynajmniej teoretycznie, kontakt między obcymi ludźmi: nadawca, nawet podpisujący się imieniem i nazwiskiem czy dokonujący szczegółowej autoprezentacji, a tym bardzicj - anonimowy (co nie należy do rzadkości) nie jest znany osobiście czlonkom redakcji. Z drugiej strony — korespondent, prawie zawsze indywidualny, kieruje swoją wypowiedź do odbiorcy zbiorowego: do redakcji, zespołu pracowników, rzadziej - do konkretnej osoby, której funkcję lub nazwisko wybiera ze stopki redakcyjnej. Uklad ten, wzbogacony o dającą się przewidywać różnicę wieku i statusu społecznego, zdaje się przesądzać o oficjalnym charakterze kontaktów. Realizacje tekstowe ujawniaja jednak zachowania bardziej skomplikowane.

List jako struktura zamknięta formalnie, tworzona przy pomocy regul charakterystycznych dla tego typu komumikatu ${ }^{\natural}$, to sekwencja następujących po sobie segmentów o ustalonej lokalizacji i funkcji. Szczególną rolę odgrywają delimitatory początku i końca - czlony, które tak jak na przykład apostrofa i podpis już na pierwszy rzut oka ulatwiają stwierdzenie, czy dany tekst może być uważany za reprezentanta gatunku zwanego listem. Dla refleksji nad przejawami grzeczności językowej istotny staje się fakt, że właśnie fragmenty początkowe i końcowe listu zawierają szczególnie wiele aktów o charakterze grzecznościowym, takich jak powitanie, przedstawienie się, życzenia czy pożegnanie". Niniejszy szkic ograniczam do prze-

\footnotetext{
${ }^{5}$ Pismo „Milıjcic sic̨!”. o podtytule „Katolicki Dwumiesięcznik Spolecznej Krucjaty Miłości”, opatrzone imprimatur Przelożonego Generalnego Towarzystwa Chrystusowego, ma obecnic objętość 56 stron, nakład ok. 240.000 egzcmplarz;; wydawane jest ponadto, choć nicregularnic, w wersji rosyjskiej i angielskicj. Kierowane przede wszystkim do mlodzièzy. znajduje czytelników także wśród osób w dojrzalym i podeszlym wickit.

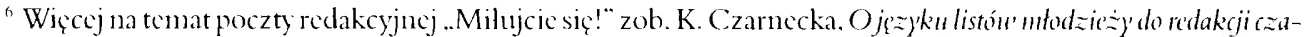

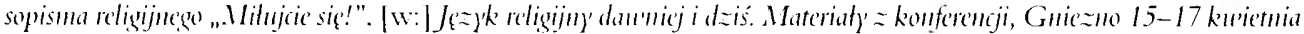
2002. red. S. Mikolajczak, T. Węclawski, P'oznań 2004, s. 389-395.

${ }^{7}$ Schemat kompozycyjny listu prywatnego opisuje m.in. K. Data, Struktura tekstu listou'ego, ,. Jczyk Polski” 1989 nr 3-5: o systemic częściowo zrytualizowanych formut powitalnych i pożenalnych zob. A. Kalkowska, Strukrma sktudniou'u listu. Wroctaw 1982, s. 51 i n. Wzorzec kompozycyjny listu do redakcji przedstawia wszechstronnic M. Wojtak, op. cit.

${ }^{x}$ K. Dati, op. cit., s. 151.

"Spośród omawianych przez M. Marcjanik (Polska grzeczność jez y kon'a, Kiclce 1997) aktów grzecznościowycl w. korespondencji do redakcji obecne są: powitanie, przedstawianic siç, życzenia, gratılacje, dodatnie wartościowanie partnera. prośba, podziçkowanie, przeproszenie, pożcgnanie, sporadycznie: deklaracja pomocy i zaproszenic. Brak: przedstawiania osób trzecich. wyrazów wspólczucia, częstowania, deklaracji podleglości przcjścia na ty: toastu.
} 
glądu niektórych zjawisk, występujących w początkowych partiach listu, przed podjęciem przez nadawcę właściwego tematu.

Wśród czlonów inicjalnych, obecnych w korespondencji do redakcji, istotne miejsce zajmują dwa elementy, nie zawsze obligatoryjne: zwrot do adresata oraz powitanie. Apostrofa umożliwia zidentyfikowanie założonego odbiorcy. W analizowanym materiale dominują formuły „Droga Redakcjo” lub „Kochana Redakcjo” (takze szeregowo: „Kochana i Droga Redakcjo!”), doprecyzowane ewentualnie o wskazanic tytułu: „1)roga Redakcjo “Miłujcie się,”/ pisma "Miłujcie się»/ czasopisma "Miłujcie się»/ dwumiesięcznika "Miłujcie się"” "lub redukowane do postaci „Kochane / Drogic "Milıjcie się!»”. Wzorzec ten, doskonale znany z rubryk różnycl czasopism, nie musi oddawać rzeczywistego zaangażowania emocjonalnego nadawcy. Nagłówki typu: „Kochani”, „Moi Kochani”, ..Moi Drodzy” nie tyle sugerują bliską więź, co odzwierciedlają znajomość konwencji. W pojedynczych wypadkach zwracano się do „Drogich redaktorów / Drogich dziennikarzy "Miłujcie się»”. Rzadko pojawiają się epitety sygnalizıjące postawę szacunku, np. „Szanowna” czy nawet ... Czcigodna Redakcjo”. Korespondenci, decydują̧cy się na zwrot do konkretnej osoby, uwzględniają zwykle imię adresata, poprzedzając je określeniami o ciepłym zabarwieniu, na przykład .Kochana Pani Tereso!!!”, „Drogi Ks. Mieczysławie” (w wersji łamiącej zasady poprawności językowej, z nazwiskiem: „Drogi Księże Mieczysławie Piotrowski”). Wyjątkową pozycję zyskał tu autor utrzymanego w serdecznym tonie cyklu artykulów, przeznaczanych przeważnie dla dziewcząt, podpisujący się jako „Twój starszy brat Jaś Bilewicz”. Kierowana do niego poczta wyróżnia się doborem familiarnych określeń, ujawniających — podobnie jak cale listy — zaufanie i poczucie bliskości; przytoczmy dla przykładı:

Kochany mój Bracic Jasiu!!!

Braciszku!

Drogi Jasiu! / Jaśku! / Janku!

Kochany Jaśku!

Drogi starszy bracie Janie.

List do redakcji można traktować również jako sposób kontaktowania się nie tylko z zespołem opracowującym czasopismo, ale i z jego czytelnikami. Intencję taką ujawniają apostrofy:

Kochana Redakcjo „Miłujcie się”, i wy kochani Czytehnicy tej wspanialej gazety;

Drodzy Czytelnicy i wy, Redakcjo;

\footnotetext{
"I Wykrzyknik w tytule czasopisma jest prawic zawsze pomijany przez autorów listow. Wszclkic wyimki z korespondencji przytaczane są z zachowaniem oryginahnego ksztaltu językowego. lącznic z wszelkimi niekonsekwencjani pisownianymi, dotyczącymi m. in. grzecznościowego zastosowania wiclkicj litery
} 
Droga Redakcjo, drodzy młodzi lıdzie!

Drodzy czytelnicy i wspaniala redakcjo!

Wśród realizacji nietypowych uwagę zwracają dwa rozwiązania. Pierwsze z nich polega na zastosowaniu formuly oficjalnej: zwrotu „Do redakcji” albo pełnego adresu pocztowego: "Miłujcie się" / ul. Panny Marii 4/60-962 Poznań — przy czym oba cytaty pochodzą z listów nieprzychylnych, wręcz buntowniczych. Drugie przyjmuje postać opisową - autor rezygnuje $z$ apostrofy, zastępując ją otwierającym list wskazaniem wirtualnego odbiorcy:

moje słowa kieruję do wszystkich tych, którzy utracili wiarę w siebie, w swoje możliwości a przede wszystkim w Boga i Matkę Boską.

Mimo iż czasopismo ma charakter wyznaniowy, tylko wyjątkowo apostrofa zawiera elementy o nacechowaniu religijnym, np. „Umilowani w Chrystusie Bracia i Siostry!”, lub zdradza znajomość uroczystego zwyczaju, nakazującego zwracać się do kapłana „Czcigodny księże”.

Kolejnym elementem, wspóltworzącym czlon inicjalny listu do redakcji, jest powitanie. Przybiera ono niekiedy ksztalt aktu bezpośredniego ", wyrażającego zamiar przywitania, np. „Witajcie!”, „Witam serdecznie!!!”, „Witam serdecznie całą redakcję Miłujcie się”. Powitania w rodzaju „cześć” odwolują się do formul grzecznościowych wyrażających szacunek dla odbiorcy, obecnie stanowią jednak dowód zmnicjszenia dystansu między partnerami ${ }^{12}$. W przeciwieństwie do neutralnych światopoglądowo apostrof, wśród powitań typu pośredniego wyraźnie przeważają pozdrowienia religijne, takie jak tradycyjne „Niech będzie pochwalony Jezus Chrystus” (czasami wraz z odpowiedzią: „na wieki wieków amen”), rozpowszechnione przez Radio Maryja „Niech będzie pochwalony' Jezus Chrystus i Maryja zawsze Dziewica”, a także życzeniowe ..Szczęść Boże”. Z praktyki niektórych wspólnot religijnych pochodzą pojedynczo występujące pozdrowienia: „Alleluja!”, „Pokój i Dobro”, „Króluj nam Chryste”.13.

Omawiane dotychczas zwroty do adresata i powitania występowaly w badanej korespondencji oddzielnie - nadawcy wybierali tylko jeden z elementów, na przykład poprzestawali na samej apostrofie ${ }^{1+}$. Redakcyjnia poczta obfituje także w przykłady struktur rozbudowanych, dwuskladnikowych. Chętniej wybierano kolejność: powitanie plus apostrofa - na przyktad:

\footnotetext{
.Jako bezpośrednic traktuje siç takic akty. których funkcja (np. podziçkowanic. przeproszenic) wyrażona jest explicite w' samcj ich formic" - M. Marcjanik. Et)'kicta jez)'kou'a, op. cit.. s. $27 \overline{5}$.

"Wśród powitaí odnotowano także pojedyncze użycia życzenia ..Dzicí dobry”, młodzicżowe „.Haj” (o proweniencji angielskiej) oraz stylizowanc ".Ciao, ciao" (w liścic wystanym z Wloch).

${ }^{13}$ Wypowiedzcnia ..Bóg jest milością"...Przez Maryję do jezusa”, lokowanc przed lub po apostrofic, w miejscı waściwym dla powitania, mają zapewne status motta. Przypuszczenic to zdają siç potwierdzać zapisy bardzie jednoznacznc. jak up. rozpoczçcic listu od slów: zaczerpniçtyclı z pism św: Faustyny: „In wiçkszy grzesznik tym wiçksze ma prawo do milosicrdzia mojego".

${ }^{4}$ Trzeba zaznaczyć, że niewiclka część osób (poniżej 5\%) rezygnuje z zanieszczenia obu tych aktów, rozpo czymając list od dalszych scgmentón:
} 
Niech będzie pochwalony Jezus Chrystus! Droga Redakcjo czasopisma „Mihujcie się" i wszyscy jego czytelnicy!,

mniej popularny okazuje się układ odwrotny:

Szanowna Redakcjo. Niech będzie pochwalony Jezus Chrystus.

Bogatsza struktura owocuje nie tylko różnicami ilościowymi; w zapisach obejmujących dwa akty odnajdujemy niewystępujące osobno formuly, jak:

Pax Christi! Kochana Redakcjo „Miłujcie się”,

parafrazę pozdrowienia:

Nied będzie podhealony' Jezus Mitosiemn' i Manjja Matka Jego. / Moi Kochani! życzenie:

Moi Drodzy! Niedi Jezus Chry'stus bedzie z Wami!

oraz - kilkakrotıie - skrótowiec, zastçpujący stosunkowo dlugic, dobrze znane pozdrowienie religijne:

Droga Redakcjo czasopisma „Miłıjcie się" / Na początku NBPJCh/ ${ }^{15}$.

Niespójność stylistyczna zwrotów grzecznościowych prowadzi do niezamierzonego komizmu:

\section{Cześć bracia i siostry!}

Zgodnie z opisywanym w literaturze przedmiotu schematem kompozycyjnym publikowanego listu do redakcji, bezpośrednio po zwrocie do adresata i/ lub stowach powitania moga nastapić, pojedynczo lub w postaci struktury złożonej z kilku działań, takie segmenty wstępne, jak autoprezentacja, pozdrowienia, uzasadnienie pisania i ocena pisma ${ }^{16}$. Pierwsze dwa mieszczą się niewątpliwie w typologii aktów grzecznościowych; podobnie - opinia o czasopiśmie zbliża się częstokroć do komplementu o dużej mocy perswazyjnej ${ }^{17}$. Aunaliza niedrukowanej korespondencji upoważnia do odnotowania występującego w tej części tekstu epistolarnego życzeń, przeprosin, podziękowań lub specyficznych formul o proweniencji religijnej, które towarzyszą pozdrowieniom. Pozdrowienia o charakterze bezpośrednim (różne

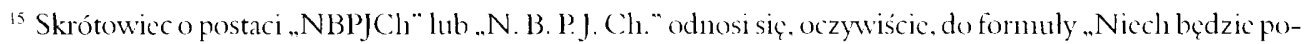
chwalony Jezus Chrystus".

it M. Wojtak, op. cit., s. 201-202: K. Data wyróżnia w tej części listu. zwancj wstẹpem, podziçkowanic, przcproszenic i powód pisania.

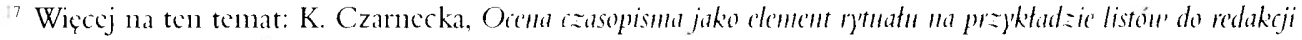

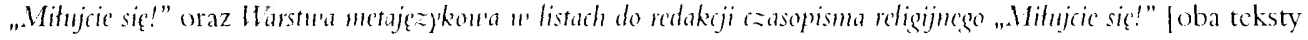
w drukul.
} 
od powitań) poprzedzane są prawie zawsze standardowym metatekstem, powtarzanym przez pokolenia w listach prywatnych: „w pierwszych słowach mojego listu / na wstępie mojego listu/ na początku”. Dalej pojawia się właściwe pozdrowienie, w skład którego, oprócz czasownika lub zwrotu wyrażającego samo działanie (,pozdrawiam”, „przesyłam pozdrowienia”) wchodza. w różnych konfiguracjach, inne elementy: wskazanie odbiorcy (na przykład: „was i wszystkich waszych czytelników”; „was wszystkich”; „Was”; „Cię”; „całą redakcję dwumiesięcznika "Miłıjcie się»”; „Panią”; „księdza”; „wszystkich braci i Siostry”), nazwa miejsca, z którego pozdrowienia nadchodzą („z ciepłego Radzynia”; „z malej parafii Brojeckiej pod wezwaniem Najświętszego Serca Pana Jezusa”), określenie związane z barwą emocjonalną (,serdecznie”, „gorąco”, ,.mile”, „bardzo mocno”). Pozdrowienia te w znakomitej większości nie różnią się od sformulowań znanych z innych rodzajów korespondencji; wyjątkowy kształt zyskują, dla przykładu, we fragmencie:

Serdecznie Was pozdrawiam w naszym Panu i najlepszym Przyjacielu Jezusie Chrystusie.

Wstępne podziękowania dotyczą najczęściej wybranych artykułów przeczytanych w „Mihujcie się!” lub też wyrażają ogólną wdzięczność za redagowanie dwumiesięcznika i za jego oddziaływanie - tym samym zbliżają się do wspommianej już opinii o periodyku. Rzadziej nawiązują do poczty otrzymanej z redakcji ${ }^{1 \times}$. Religijny profil czasopisma zachęca do wykorzystania odpowiedniej stylistyki:

Bóg wam za to zapłać;

dziękuję Bogu za Waszą pracę;

Dziękuję dobremu Bogu za Was, za Waszą działalıość.

Motywy religijne ujawniają się także w nielicznych życzeniach:

Na początku mojego listu serdecznie pozdrawiam i przesylam moc serdecznych życzeń, z okazji zblizających się Świąt Bożego Narodzenia. Życzę z całego serca, aby Dzieciątko Jezus zamieszkalo w naszych sercach. Niech to oczekiwanie na Pana będzie wielką radością;

Na wstępie mego krótkiego listı pozdrawiam Was i też całe Zgromadzenie Towarzystwa Chrystusowego, życzę Wam wiele lask Bożych w Waszym życiu oraz w rozwoju Waszego czasopisma.

\footnotetext{
"* W zespole redakcyjnym ..Milıjcie siç!" obowiązıje zasada odpowiadania na listy czytchiników. Przeproszcnia. lokowane we wstępnych partiach listów do redakcji, dotyczą m.in. zwloki w odpowiedzi na przesylkę od .Milujcie się!”. np. ..Na wstępic mojego listu bardzo serdecznic i gorąco Was pozdrawiam i przcpraszam, żc depicro teraz piszę".
} 
Odrębnym aktem, o strukturze odmiennej od życzeń, jest polecenie adresata opiece Niebios:

Na wstępie mojego listu serdecznie wszystkich pozdrawiam i polecam opiece Matki Boskiej Rózańcowej.

Jak już wspomnialam, początkowe partie listu wyróżniają się nagromadzeniem wypowiedzeń służących tworzeniu atmosfery grzecznościowej. Osoba pisząca list wybiera przeciętnie 3-4 akty z opisywanego powyżej repertuaru. Podobnie ksztaltuje się zakończenia listów. W pozycji finalnej pojawiają sic̨ formuly, których można użyć na początku (powtarzane lub wprowadzane po raz pierwszy); do tej grupy należą pozdrowienia, życzenia, komplementy, podziękowania za czasopismo. Wyłącznie na końcu umieszcza się podziękowania za przeczytanie listu, przeprosiny za jego długość, za uchybienia kompozycyjne i językowe, prośby o odpowiedź, a także o ewentualną publikację listu lub o jej zaniechanie ${ }^{1 ')}$. Kumulacja aktów grzecznościowych sprawia, że stanowią one swoistą ramę, okalającą właściwą treść. W części centralnej można znaleźć prośby, będące bezpośrednim powodem zredagowania listu (prośby o radę, odpowiedź na pytanie, rozstrzygnięcie problemu, pomoc materialną, w sprawach związanych z kolportażem, zamawianiem książek itp.); inne wyrazy grzeczności są tam na tyle rzadkie, że trzeba je uznać za zjawisko marginalne.

Formy grzecznościowe obecne w poczcie nadchodzącej do redakcji „Milujcie się!” wykazują podobieństwa do struktur charakterystycznych dla korespondencji prywatnej; zwracająca uwagę pewna nadmiarowość elementów byłaby niestosowna w lakonicznych, wyważonych pismach oficjalnych, urzędowych. Wolno przypuszczać, że ów nadmiar może się wiązać z trudną, a przynajmniej niecodzienna sytuacją komunikacyjną. Fragmenty metatekstowe, wplatane w tok wypowiedzi epistolarnej, sygnalizują niepewność nadawców, którzy borykają się z doborem środków odpowiednich przy zwracaniu się do osób obcych, tylko wyobrażanych na podstawie lektury czasopisma. Korespondenci pragną zazwyczaj pozyskać przychylność czlonków redakcji; w swej bezradıości sięgają po wzorce adekwatne przy kontakcie partnerów o nierównych pozycjach. Tematyka listów bywa wszakże bardzo osobista, wręcz intymna - odbiorcy traktowani sąjak powiernicy, najlepsi przyjaciele, spowiednicy, psychologowie. Zaangażowanic emocjonalne mlodych autorów prowadzi często do zmniejszania dystansu, a w konsekwencji - do stylistyki, która byłaby naturalna w relacji rówieśniczej. Sytuację komplikuje kontekst religijny. Niedostateczuna sprawność językowa prowadzi do łączenia (albo mieszania) środków zaczerpniętych z różnych porządków stylistycznych — słownictwo języka ogólnego sąsiaduje z frazeologią biblijna, sformułowania podniosłe, książkowe z leksyką potoczna albo środowiskową (socjolekt mlodzieżowy). Model grzeczności językowej wyłaniający się z analizowanych listów nie jest więc jednorodny - oscyluje pomiędzy starannymi (choć nie zawsze fortmnnymi) wyborani o zabarwieniu oficjalnym a bezpośrednim tonem, który niekiedy graniczy z poufatością.

1" Zdarza siç równicz ponowienie prośby, będącej przedniotem korespondencji, a wyrażonej już w cz̨̧ści centralncj. 